\title{
EDUCAÇÃO E IMIGRAÇÃO NA PROVÍNCIA DO PARANÁ: ANÁLISE DA CONSTITUIÇÃO DAS ESCOLAS ÉTNICAS PARA OS FILHOS DE IMIGRANTES
}

\author{
Vera Lucia Martiniak
}

UEPG

\section{RESUMO}

Este texto apresenta uma análise da institucionalização das primeiras escolas étnicas no Paraná, no início da organização política e administrativa da Província do Paraná. Após a emancipação o governo paranaense implementou e iniciou um processo imigratório colonização, com ocupação dos espaços vazios propícios ao desenvolvimento da agricultura, o comércio e indústria e a substituição do trabalho escravo pelo trabalho assalariado. Assim, houve o incentivo ao desenvolvimento das cidades, que estimulou o comércio e fomentou a criação de serviços de infra-estrutura. Neste contexto histórico procura-se compreender a importância da atuação e a influência das escolas étnicas para a organização educacional no Paraná. O eixo teórico-metodológico permite reconstruir uma história totalitária, analisando os determinantes econômicos, políticos e sociais tendo como pressuposto o materialismo histórico-dialético. Para compreender a institucionalização das escolas étnicas no Paraná, partiu-se da análise dessa conjuntura, bem como o levantamento e catalogação das fontes primárias e secundárias, selecionadas em instituições públicas, museus e acervos particulares.

Palavras chave: Instituições escolares; Imigração; Escolas étnicas

\section{IMMIGRATION AND EDUCATION IN THE PROVINCE OF PARANA: ANALYSIS OF THE CONSTITUTION ETHNIC SCHOOLS FOR THE CHILDREN OF IMMIGRANTS.}

\begin{abstract}
This paper presents an analysis of the institutionalization of the first ethnic schools in Parana, early in the political and administrative organization of the Province. After emancipation the Paraná government implemented a process immigration and colonization began with the occupation of empty spaces conducive to the development of agriculture, trade and industry and the replacement of slave labor by wage labor . Thus, there was encouraging the development of cities, which stimulated trade and encouraged the setting up of infrastructure. In this historical context we seek to understand the importance of the role and influence of ethnic schools for the educational organization in Paraná. The theoretical-methodological axis allows to reconstruct a totalitarian history, analyzing the determinants of economic, political and social taking for granted the historical and dialectical materialism. To understand the institutionalization of ethnic schools in Paraná, started from the analysis of this situation, as well as surveying and cataloging of primary and secondary sources , in selected public institutions, museums and private collections .
\end{abstract}

Keywords: educational institutions. Immigration. ethnic schools 


\section{Introdução}

O presente texto tem como foco central a análise do processo imigratório estimulado pelo governo paranaense e a constituição das primeiras escolas étnicas, criadas no interior das colônias para atender os filhos dos estrangeiros. Para empreendimento da análise utilizou-se como referencial teórico o materialismo histórico-dialético, que busca descrever a realidade do fenômeno estudado de modo a atingir a sua essência, uma vez que "[...] captar o fenômeno de determinada coisa significa indagar e descrever como a coisa em si se manifesta naquele fenômeno, e como ao mesmo tempo nele se esconde"(KOSIK, 1995, p. 16). Assim, pretende-se desvelar as contradições existentes centrando-se na análise da totalidade e seus determinantes econômicos, políticos e sociais que desencadearam a vinda dos imigrantes a partir da década de 1850 para o Paraná. Nesta perspectiva, considerar-se-á um contexto mais amplo, considerando a totalidade histórica do período definido marcado pela mudança da estrutura da sociedade baseada no trabalho escravo para o trabalho assalariado.

Com base neste referencial teórico, buscou-se por meio do levantamento e catalogação de fontes primárias e secundárias identificar a constituição das escolas étnicas no Paraná e as práticas educativas vivenciadas nas colônias. Para a consecução desta pesquisa foram utilizados os Relatórios dos Presidentes da Província, Relatórios da Secretaria de Instrução Pública e documentos pertencentes a acervos públicos e particulares referentes a imigração e escolas de imigrantes.

A questão norteadora desta pesquisa centrou-se na seguinte questão: Como se deu o processo de escolarização na Província do Paraná para atendimento das crianças filhas de imigrantes?

Entende-se que no final do Império a educação tornou-se progressivamente uma prática institucional-escolar, isto é, realizada na instituição que historicamente especializou-se na tarefa educativa, ou seja, a escola. Este processo de institucionalização escolar deu-se no decorrer do Império, observadas as especificidades com respeito aos níveis e modalidades educacionais. Há que se considerar ainda, que no decorrer deste processo, devido a profundas mudanças nas relações de produção (do trabalho escravo para o trabalho assalariado) ocorreram iniciativas particulares para a organização de escolas nos centros urbanos. Desta forma, esta pesquisa buscará compreender diante do contexto histórico e das dessincronias das políticas públicas o processo educativo das crianças imigrantes no Paraná.

A análise centra-se na imigração devido a região paranaense ser constituída por diversos imigrantes que fundaram colônias e que mais tarde deram origem as cidades. Desta forma, há um predomínio muito grande de diversas etnias que demonstraram diversas formas de organização social e também educacional. Em relação a educação das crianças imigrantes registra-se uma iniciativa singular de criação de escolas comunitárias de imigrantes, principalmente alemães, italianos, poloneses e japoneses que se estabeleceram em áreas rurais formando núcleos populacionais com características e estruturas marcantemente étnico-culturais. As escolas por eles criadas eram comunitárias e tinham uma conotação fortemente étnica e confessional cristã. Além destas escolas comunitárias, houve um número significativo de escolas particulares mantidas por congregações religiosas, masculinas e femininas, geralmente em área urbana, mantendo especificidades étnicas do país de origem da mantenedora (KREUTZ, 2000). Neste contexto, as escolas para imigrantes desempenhavam um importante papel na aquisição das primeiras letras, pois, concebiam a instituição escolar como um lugar de civilização do homem, preservação e valorização da cultura 
estrangeira e como mecanismo para "[...] suprir a inexistência de escolas mantidas pelo poder público [...]” (LUPORINI, 2006, p. 311).

\section{$O$ contexto brasileiro $\mathrm{e} o$ incentivo à imigração europeia}

A história da imigração no Brasil divide-se em três fases distintas: a primeira compreende o período de 1808 a 1850; a segunda, de 1850 a 1888; e a terceira, de 1888 a 1950 (DIEGUES JÚNIOR, 1964). No primeiro período, o governo de D. João VI adotou medidas de incentivos em favor da imigração, favorecidas pela abertura dos portos ao comércio estrangeiro. No segundo momento, com a proibição do tráfico de escravos, a mão-de-obra imigrante veio substituir e complementar a escassez do trabalho escravo. Esta situação favoreceu e estimulou à entrada do trabalhador branco e livre (DIEGUES JÚNIOR, 1964). E por fim, a terceira fase, marcada pelo fim do escravismo e com incentivos públicos e particulares para a entrada de novos grupos de imigrantes.

O primeiro período de entrada de estrangeiros no Brasil é marcado pela dificuldade para a obtenção de escravos para o trabalho braçal, devido à legislação em vigor no período ${ }^{1}$. Para solucionar esta questão o governo imperial iniciou uma campanha para acelerar a entrada de estrangeiros para substituir a mão-de-obra escrava. O primeiro grupo de imigrantes chegou ao Brasil em 1819. Eram cerca de 1700 suíços de língua alemã, provenientes do Cantão de Friburgo, que o governo instalou no Rio de Janeiro, onde fundaram, em 1820, a atual cidade de Nova Friburgo. Em 1824, teve início a colonização alemã em São Leopoldo, no Rio Grande do Sul. Em 1827, outra colônia alemã foi instalada em Rio Negro, no Paraná. Em 1829, foi fundada uma colônia alemã em Santo Amaro (SP) e outra em São Pedro de Alcântara (SC). Em 1830, foi criada uma colônia alemã no Espírito Santo. É importante frisar que os imigrantes europeus não vieram ao Brasil com o principal intuito de enriquecimento rápido; muitos saíram de sua terra de origem por questões ou problemas sociais, econômicos ou políticos. A Alemanha, especificamente, como não havia colônias para as quais pudesse repassar os excedentes populacionais e com uma expansão industrial tardia para absorver os egressos do campo, a emigração passou a ser fenômeno desejável para contornar as tensões sociais provenientes do aumento demográfico (KREUTZ, 1991).

Além de favorecer a entrada do trabalhador branco e livre, o incentivo à imigração, possibilitou o branqueamento da população como um dos objetivos implícitos do governo brasileiro:

[...] as elites diretivas do Brasil pensavam numa forma de impedir que o país se tornasse a maior nação negra do planeta, tamanho era o número de africanos trazidos ao Brasil desde o século XVI. Era o problema do caiamento da população.

Segundo essas elites, era preciso tornar o país majoritariamente branco e não africano. Dentro dessa conjuntura, resolveu o governo imperial acelerar a imigração européia para o país (WACHOWICZ, 2001, p. 145-6).

Pode-se considerar que a imigração no Brasil, na maioria das vezes, foi provocada, e raramente aconteceu espontaneamente. Por esse motivo, as maiores entradas coincidiram com períodos em que houve escassez de mão-de-obra na lavoura e com a intensificação da propaganda brasileira no exterior. Os objetivos de ordem interna que incentivaram a imigração relacionaram-se com um quadro europeu favorável, no qual o período de maior intensidade, entre os séculos XIX e XX, assistiu 
transformações econômicas e sociais. Nesse quadro de transformações, desencadeado pela Revolução Francesa e a Revolução Industrial, os camponeses encaminhavam-se para os centros urbanos, expulsos das grandes propriedades agrícolas. A industrialização, que se restringiu primeiramente à Inglaterra, avançou no continente, obrigando os trabalhadores a aceitar baixos salários e jornadas de trabalho exaustivas. Essas condições de vida paupérrimas, aliadas ao desenvolvimento do capitalismo europeu, que favoreceu a melhoria dos transportes tanto marítimos quanto terrestres, encaminharam para diversas regiões do mundo indivíduos e grupos de diversas nacionalidades.

Assim, o movimento de colonização trazia em seu bojo uma série de objetivos que demonstravam a proposta do movimento imigratório brasileiro. Entre eles, a ocupação dos espaços vazios propícios ao desenvolvimento da agricultura, do comércio e da indústria e a substituição da força de trabalho escrava pela força de trabalho assalariada. Dessa forma, haveria o incentivo ao desenvolvimento das cidades, que estimulariam o comércio e fomentariam a criação de serviços de infra-estrutura.

Ocuparia espaços vazios, promoveria a valorização fundiária e criaria condições para uma camada social intermediária entre latifundiário e escravo, uma camada de mercado consumidor, de diversificação da economia e de produção de gêneros para os quais a grande propriedade não se prestava. (KREUTZ, 1991, p. 46)

A vinda dos imigrantes também contribuiu para a organização dos trabalhadores em sindicatos e associações, com o objetivo de defender seus interesses e lutar por melhores condições de trabalho. Nesse movimento, as organizações anarco-sindicalistas conviveram com as associações de auxílio mútuo: as "[...] lutas pelo rebaixamento dos gêneros alimentícios estarão ao lado de reivindicações por salários, jornada de trabalho, assim como pelo congelamento dos aluguéis, a forma predominante no período"(GOHN, 1995, p. 61).

Todavia, o governo brasileiro tratou essa questão social como uma questão de polícia, por meio do controle de políticas e leis restritivas à entrada de trabalhadores imigrantes e, também, por meio de

[...] criação de programas sociais integrativos, pelo empresários vilas operárias, por exemplo, pela Igreja Católica - sessões de cinema mudo, ou pelo próprio Estado - controle sanitário da população, constituem respostas por partes das elites dominantes à organização das camadas pobres e oprimidas, particularmente às ações dos imigrantes, por meio do anarco- sindicalismo. (GOHN, 1995, p. 62).

Por meio dessas ações, o governo brasileiro procurou inibir a ação do movimento anarcosindicalista, conjuntamente com a criação de instrumentos para a regulamentação do trabalho por meio de legislação, de forma a amenizar a insatisfação que motivou as lutas travadas pelos trabalhadores desde o início do século. Os anarquistas eram em sua maioria imigrantes europeus, principalmente italianos, espanhóis e portugueses, que vieram para o Brasil para trabalhar na lavoura, sendo depois recrutados pelas indústrias nascentes por serem uma mão-de-obra considerada mais apta que a dos ex-escravos. Neste sentido, reforçar-se os motivos que justificariam a vinda de imigrantes: fornecer mão-de-obra para a grande lavoura do café, que estava ameaçada pelos movimentos abolicionistas na metade do século passado. 
O trabalho assalariado tornou-se dominante e o Abolicionismo, a princípio um movimento social amparado apenas nas camadas médias urbanas e que foi ganhando para si a adesão das classes proprietárias dos estados não-cafeeiros, na medida em que o café passou a drenar para si escravos de outras regiões, que recebeu respaldo do núcleo dominante da economia cafeeira. Abolicionismo e Imigrantismo tornaram-se uma só e a mesma coisa, até que em 1888 a escravidão foi extinta (MELLO,1998).

\section{A chegada dos imigrantes no Paraná}

Ao longo do século XVIII e parte do século XIX a sociedade paranaense se estruturou com o progresso da pecuária e do tropeirismo, fazendo com que as fazendas de criação se tornassem auto-suficientes e seus proprietários acumulassem grande capital. As propriedades possuíam autonomia econômica, produziam a própria alimentação, o vestuário, os móveis, os instrumentos de trabalho, o material para a construção das casas, entre outros (IANNI, 1988). A composição familiar era marcada por uma dupla estrutura, formada pelo núcleo central do casal e seus filhos e de uma estrutura periférica formada pelos escravos, agregados (brancos livres e pobres, bem como libertos), índios, negros e mestiços, concubinas e filhos ilegítimos do senhor, construindo um novo mundo social, econômico e humano (IANNI, 1988). Os agregados trabalhavam nas terras das fazendas exercendo as funções de capatazes, feitores, capangas e vigilantes das invernadas mais longínquas. Já, o escravo consistiu na força propulsora da atividade pecuária, mas também esteve presente na mineração, na agricultura de subsistência, no cultivo da erva mate e do café.

A utilização da mão-de-obra escrava esteve presente, paralelamente a do trabalho livre, na produção do mate, desde a colheita até o preparo e o fabrico da erva, realizando as tarefas mais árduas e enfrentando longas jornadas de trabalho. Do ponto de vista econômico, a adoção do trabalho escravo tornou-se uma medida rentável para os senhores de engenho como para os traficantes de escravos, pois nesta perspectiva, o escravo era somente um bem de consumo."Mas não é somente a força de trabalho que é mercadoria; eles próprios são mercadoria, pois são colocados entre os meios de produção pelos seus proprietários".(IANNI, 1988, p. 112).

Somando-se a exploração da força de trabalho escrava, as condições de trabalho nos engenhos eram precárias e sofríveis, pois o negro “[...] na visão da economia agroexportadora, surge como um animal racional, capaz de realizar basicamente tarefas manuais, a fim de suprir a necessidade de mão de obra que até então se apresentava" (ABREU, 2009, p. 51).

Na produção de erva-mate aos poucos foram sendo implantadas novas técnicas de beneficiamento do mate que consequentemente melhoraram a sua qualidade e possibilitaram assim, conquistar os mercados internacionais da Argentina e Uruguai, deixando o Paraguai fora da competição.

É muito possível que o satisfatório crescimento da exportação desse produto tenha beneficiado duplamente a economia de subsistência da região paranaense, pois as populações do interior puderam aumentar sua renda real, dedicando se à extração da erva, enquanto a urbana, de Curitiba e do litoral, viu expandir, pelo efeito multiplicador, o mercado interno (PADIS, 2006, p. 80).

Com a mecanização dos engenhos e a utilização do motor a vapor, a mão-deobra escrava foi gradativamente diminuindo. A substituição da força de trabalho escrava 
foi resultante de mudanças qualitativas na produção ervateira e da renovação tecnológica decorrente do aumento das exportações do produto (IANNI, 1988). Para o trabalho no engenho era necessária qualificação para manuseio das máquinas e isso foi possível a partir do incentivo da imigração européia, pois a maioria dos fazendeiros acreditava na superioridade do trabalho livre. Por outro lado, havia uma oposição muito forte contra a abolição do trabalho escravo, pois o escravismo foi altamente rentável na medida em que satisfazia os interesses dos proprietários dos meios de produção.

Enquanto que os esforços e recursos foram empregados na atividade ervateira, as demais, como a pecuária, entraram em decadência. Em 1881, o presidente da província, João José Pedrosa salientou a necessidade de instruir o "caipira" com instrumentos e processos aperfeiçoados para que pudesse tirar melhor proveito da terra, utilizando também a agricultura como meio de subsistência.

- Quaes os ramos da industria que os paranaenses devem explorar, tendo em vista as condições da terra, os gastos da producção e os mercados consumidores?

- eis ahi problemas complexos, para cuja solução tornam-se precisos certos conhecimentos, certa instrucção que os nossos lavradores ainda não possuem, e que só irão adquirindo à proporção que o nível intellecutal da província for subindo.

Trabalharemos, pois, de modo a propagar o ensino, dando as novas gerações dos districtos ruraes uma boa instrucção agrícola à par da rudimentar, distribuindo-se pelas escolas bons compêndios de agricultura e não apenas os cathecismos, $\{\ldots\}$

Favoreçamos a entrada de bons immigrantes, agricultores adiantados, que com o exemplo e resultado do seu trabalho aperfeiçoado, estimulem os nossos lavradores a explorarem novas producções e a abandonarem o seu systema rotineiro, penoso e pouco profícuo (PARANÁ, 1881, p. 32).

Em um contexto marcado pela decadência do regime escravo e a dificuldade de suprir a ausência de mão-de-obra livre nas lavouras, o incentivo à imigração europeia passou a ser discutida pelos governantes como solução para os problemas.

O estímulo à imigração europeia na Província do Paraná foi incentivada desde cedo, com o primeiro presidente da Província, Dr. Zacarias de Goes e Vasconcelos, conforme Lei $\mathrm{n}^{\circ}$ 29, de 21 de março de 1855 que assegurava: "Fica o governo autorizado a promover a imigração de estrangeiros para esta província, empregando neste sentido os meios que julgar mais convenientes".

O descrédito na força de trabalho nacional oportunizou aos fazendeiros a importação de trabalhadores europeus, que vinham ao Brasil, desprovidos de bens materiais e dispostos a prestarem serviços a preços aviltantes. A chegada dos imigrantes, de vários países, provocou um aumento populacional, relegando para segundo plano um exército de mão-de-obra de trabalhadores livres e libertos, que, mais uma vez, foram excluídos dos núcleos dinâmicos da economia (KOWARICK, 1994).

Com as transformações do sistema econômico, no qual estão inseridas direta ou indiretamente as comunidades brasileiras, e com as alterações da estrutura demográfica, devidas à interrupção do tráfico, a política imigratória etc., o trabalhador escravo se torna economicamente oneroso, ou inadequado às novas exigências (IANNI, 1988, p.164). 
Os governantes paranaenses incentivaram a vinda de imigrantes para a região como meio de aumentar e renovar a população corrompida pelo contato com a escravidão e também para preencher os espaços desabitados do território (TRINDADE, 2001).

A imigração para o Brasil foi incentivada pelo Governo, particularmente como substituição da mão-de-obra escrava. Assim, a maior parte dos imigrantes foi encaminhada para as lavouras de café, as quais, em razão da sua importância econômica, tinham a maior necessidade de braços para o trabalho. Um número menor de imigrantes foi estabelecido como pequenos proprietários nos núcleos coloniais etnicamente homogêneos, em especial nos Estados do Rio Grande do Sul, Santa Catarina, Paraná e Espírito Santo (NASCIMENTO, 2008, p. 41).

O Paraná, ao ser desmembrado da província de São Paulo em 1853, possuía apenas duas cidades, sete vilas e seis freguesias, e contava com cerca de 60 mil habitantes. Logo após a sua autonomia política e administrativa, o governo passou a incentivar o programa de imigração, com objetivo de colonizar as regiões mais afastadas do território paranaense. A Lei de Terras de 1850, em seu artigo 18, estabelecia que o Governo poderia mandar vir anualmente um certo número de colonos livres para serem empregados, em estabelecimentos agrícolas, nos trabalhos dirigidos pela Administração pública ou na formação de colônias. Na província havia somente duas colônias de imigrantes, uma no litoral, a do Superaguy, e outra no interior, a de Thereza (PARANÁ, 1854).

Em virtude dos fracassos dos primeiros núcleos coloniais o governo paranaense determinou ações para o estabelecimento das famílias imigrantes. Para amenizar as dificuldades determinou que as colônias deveriam estabelecer-se próximas aos centros consumidores e estradas para facilitar o escoamento da produção, além de que os colonos seriam informados quanto às condições das terras oferecidas e nas localidades mais distantes, poderiam ser construídas uma escola e uma igreja.

Essas medidas facilitaram e permitiram a fixação dos novos imigrantes, porém, foi necessário o incentivo para o povoamento de regiões mais afastadas, como os Campos Gerais, Palmeira e Lapa. A colonização desta região teve como característica principal o predomínio de imigrantes conhecidos como russos-alemães, procedentes do Volga.

É este um dos assumptos que na actualidade mais prende a atenção do governo imperial e de todos aquelles que pensam no futuro que está reservado ao nosso paiz. Povoar os nossos immensos e desconhecidos territórios, levar a vida aos sertões onde a açção dos séculos amontoou thesouros de rara valia, e que ali fazem entregues ao esquecimento, eis o grande pensamento em que se fundara todas as aspirações dos brazileiros. (PARANÁ, 1875, p. 21)

Os primeiros grupos de imigrantes que se estabeleceram encontraram dificuldades, como o acesso aos centros urbanos e terras improdutivas, ocasionando o abandono das colônias. As repercussões do fracasso chegaram à Europa e a imigração no Paraná sofreu uma diminuição considerável, sendo retomada somente a partir de 1885 com a política de sociedades de imigração para estimular o processo imigratório, centrado num discurso de que a atração à região não era suficiente, mas localizá-lo convenientemente era essencial (PARANÁ, 1884). No ano de 1861 a saída de 
estrangeiros do Estado do Paraná era superior a entrada: entraram 881 e 102 escravos e saíram 889 e 124 escravos.

Foram criadas sociedades de imigração em onze localidades da Província: Paranaguá, Curitiba, Superagui, Porto de Cima, Morretes, Antonina, Campo Largo, Lapa, Ponta Grossa, Castro e Guarapuava.

Essas associações atuaram de modo eficiente e variado na promoção de serviços de imigração, inclusive na propaganda das terras do Paraná para a colonização.

Em virtude, aliás, da intensificação da publicidade, realizada também pelas companhias concessionárias das construções de ferrovias, da abolição da escravatura e da proclamação da República, intensificou-se, nesse período, a entrada de imigrantes no Brasil, oportunidade em que são atingidas as quotas anuais mais elevadas, com mais de duzentos mil imigrantes por ano (BALHANA, 1969, p. $183)$.

Desta forma, conclui-se que o incentivo à imigração europeia teve um duplo objetivo: a ocupação do vasto território por uma população livre e branca, com a utilização de modernas técnicas agrícolas e o paulatino "branqueamento" ${ }^{3 \text { " da população }}$ brasileira (NASCIMENTO, 2008). Neste sentido, o Estado apoiou-se na perspectiva de construir uma nação por meio do aumento da população branca e miscigenação entre imigrantes e população local, promovendo a melhoria dos hábitos e costumes.

O incentivo à imigração quer para a substituição do braço escravo na grande lavoura ou para a colonização, complementavam-se, pois esperava-se que o imigrante permanecesse no país, quer como colono ou como trabalhador urbano, engrossando o contingente de "operários" nas fábricas das cidades.

As autoridades provinciais conhecedoras da situação decadente das estruturas sócio-econômicas da maioria das áreas do Paraná, alimentaram a esperança de que a introdução de novos contingentes populacionais imigrados proporcionaria condições de mudança e progresso agrários para a Província. Na verdade, a imigração, na expectativa dos seus promotores oficiais, era considerada, já há algum tempo como fator de progresso agrário. (BALHANA, 1969, p.76).

A política oficial de incentivo à imigração permaneceu até 1896 e consistiu no subsídio para o custeio da passagem, no transporte para o local da colônia, doação de lote e auxílio para manutenção nos primeiros meses. A partir de 1896, apenas o terreno era adquirido por preço pequeno e com pagamento a longo prazo.

Infere-se que a imigração no Brasil assumiu aspectos diversos, dependendo da região em que se desenvolveu, dos fins propostos, do sistema de produção, das iniciativas e dos financiamentos. Por todas essas características descritas, a imigração no Sul do país assumiu um caráter singular, que a diferenciou do processo de imigração na região sudeste.

Concederam-se aos colonos lotes de terras. Embora o processo tenha sido diferente num e noutro caso, o contingente imigrante contribuiu, tanto numa região quanto em outra, para o desenvolvimento dos núcleos urbanos e para a ampliação relativa do mercado interno, estimulando as funções urbanas. (COSTA, 2007, p. 254). 
Em relação a entrada de imigrantes no Paraná, no período de 1829 a 1934, destaca-se o volume de estrangeiros, assim distribuídos:

Quadro 1 - Entrada de imigrantes no Paraná

\begin{tabular}{|r|l|}
\hline \multicolumn{1}{|c|}{ ETNIA } & QUANTIDADE \\
\hline Poloneses & 47.731 \\
\hline Ucranianos & 19.272 \\
\hline Alemães & 13.319 \\
\hline Italianos & 8.802 \\
\hline Franceses & 2.469 \\
\hline Austríacos & 1.559 \\
\hline Espanhóis & 1.344 \\
\hline Russos & 1.330 \\
\hline Ingleses & 1.019 \\
\hline Suíços & 1.006 \\
\hline Holandeses e outros & 450 \\
\hline
\end{tabular}

Fonte: BALHANA, 1991.

O Paraná recebeu um grande número de imigrantes de origem polonesa que foram atraídos pela propaganda no exterior. Entretanto, a escolha do território e a implantação de suas colônias, seu deu além da propaganda no exterior, também pelo favorecimento do clima e do solo que aqui encontravam de forma muito semelhante ao do sul da Europa.

O estabelecimento de colônias no interior da Província garantiu a preservação do espaço territorial, criou ainda, novas rotas de abastecimento e a formação do mercado interno. $\mathrm{O}$ atendimento à demanda do mercado interno, com a produção dos núcleos coloniais, influenciou na diversificação de produtos e na busca de novos meios de transportes. A construção de ferrovias tornou-se essencial para a penetração para o povoamento do território ainda não colonizado no Paraná, favorecendo também a expansão do comércio madeireiro (BALHANA, 1969). A implantação de ferrovias na Província do Paraná iniciou a partir de 1880, com as obras de construção da Estrada de Ferro Curitiba-Paranaguá, atravessando a Serra do Mar. A indústria madeireira teve grande impulso com o aparecimento de outras ferrovias, que ligavam as regiões da Mata de Araucárias aos portos de Paranaguá, com destino a São Paulo. Com o avanço das estradas de ferro o transporte com mulas foi desaparecendo, e a economia voltou-se para a pecuária e para a exploração da madeira.

A vinda dos imigrantes incentivou o processo de urbanização no Paraná e contribuiu para o incremento das atividades agrícolas e comerciais nos Campos Gerais. O território paranaense consistia, ainda, em uma região mal povoada, com sertões desabitados. Os pequenos núcleos existentes eram dispersos e localizados no interior, como os de Guarapuava, Palmas, Rio Negro, Castro e Tibagi, que sofriam constantemente ataques de índios hostis.

O mesmo receio e desconfiança ocorria com os tropeiros que faziam a ligação de São Paulo com o Rio Grande do Sul, especialmente no trecho ao sul do Rio Negro, na chamada Estrada da Mata. Eram ali os tropeiros molestados pelos índios xokleng (botocudos), sempre prontos a um ataque de surpresa (WACHOWICZ, 2001, p. 145). 
O processo de colonização no Paraná obteve bons resultados, uma vez que as repercussões desse processo redundaram na construção de uma economia diversificada, principalmente na região dos Campos Gerais. Nesta região instalaram-se imigrantes alemães, italianos, poloneses, ucranianos, russos e outros, que formaram colônias nos arredores da cidade. Algumas comunidades organizaram-se na região já urbanizada, inserindo-se no segmento da população que tinha um trabalho vinculado às atividades consideradas urbanas, como a indústria e o comércio.

A maioria dos imigrantes dedicava-se à agricultura e à exploração de produtos nativos como a madeira e a erva-mate, mas muitos também trabalhavam com a pecuária e o comércio rural e urbano. Os primeiros núcleos imigratórios passaram por dificuldades quanto à localização de suas terras. A falta de vias de acesso para os centros urbanos, a grande distância entre as cidades e as colônias foram alguns dos fatores responsáveis pelo insucesso da colonização. Outro empecilho às colônias foi o solo improdutivo, de aspecto ácido e arenoso, provocando o deslocamento das famílias de colonos para os centro urbanos. Os fazendeiros e políticos dos Campos Gerais

[...] venderam à província as piores terras, imprestáveis para a agricultura. Já após a primeira plantação revelaram ser totalmente impróprias. Entre os aproximadamente 3.800 russos- alemães que aportaram ao Paraná, cerca da metade abandonou a província. Em levas de grupos famintos, a pé, dirigiam- se a Paranaguá a fim de abandonar o Brasil (WACHOWICZ, 2001, p.153).

Os poucos imigrantes russos-alemães que permaneceram dedicaram-se ao transporte da erva-mate do interior até os Portos de Antonina e Paranaguá.

Em 1890 instalaram-se nos Campos Gerais, no núcleo Cecília, cerca de 150 italianos, que incentivados pelo engenheiro Giovanni Rossi tentaram organizar-se a partir dos ideais anarquistas. Entretanto, depararam-se com vários obstáculos, entre eles a dificuldade com o tipo de solo a que estavam acostumados a preparar para a plantação, o tempo que a cultura plantada levava para atingir o período de colheita, a falta de matéria-prima, ferramentas e principalmente, de recursos financeiros. Esses imigrantes, que eram também artesões, tiveram que adaptar-se a outras atividades. Para sobreviverem, procuravam outros afazeres fora da colônia, como o trabalho na construção da Estrada que ligava Serrinha a Santa Bárbara. Assim, com os salários que recebiam auxiliavam os companheiros que trabalhavam somente na colônia. De princípio, a estratificação social não chegou a ser perceptível no interior da Colônia, pois todos participavam dentro das possibilidades pessoais e grupais. No entanto, os colonos não puderam manter-se afastados das condições existenciais das comunidades, próximas e distantes, com as quais interagiram por meio de ligações comerciais. Já no primeiro ano de assentamento, os colonos anarquistas tiveram problemas com suas terras. O governo do Estado do Paraná outorgou uma lei segundo a qual todas as terras das colônias que fossem ocupadas sem pagamento algum, seriam cobradas imediatamente. Como o núcleo Cecília tinha sido concedido apenas pela palavra de D. Pedro II, os moradores tiveram problemas com o governo.

Decidiram que só pagariam a dívida se a colheita do milho rendesse algum capital. Essa colheita de 1893 - principal fonte econômica - seria utilizada para o pagamento da dívida colonial das terras, porém, José Gariga, que foi acolhido pela colônia, vendeu toda a safra de milho e fugiu com o dinheiro. 
Aliado a esse problema, o vírus do crupe fez com que muitas pessoas abandonassem a colônia para tentar a sorte em outros lugares e, com isso, ocorreu o fim da tentativa anarquista no sul do Brasil. Em 1897, a colônia Cecília já não existia mais na prática; contava com apenas alguns moradores, que não tinham para onde ir.

A idéia de uma sociedade igualitária teve pouca duração nos Campos Gerais; o ideal anarquista se refletiu nas assembléias, nos barracões coletivos, na divisão igual de alimentos, nas multifunções que todos exerciam, na inexistência de cercas para a delimitação da área, no acolhimento de visitantes e no respeito à opinião alheia. Entretanto, os ideais libertários tiveram uma repercussão nos meios literários e no movimento sindical no Brasil. A educação ocupou posição central ao expressar-se num duplo movimento: "[...] a crítica à educação burguesa e a formulação da própria concepção pedagógica que se materializava na criação de escolas autônomas e autogeridas". (SAVIANI, 2010, p 182).

Além dos italianos, o Paraná foi ocupado por imigrantes japoneses que fundaram núcleos importantes como de Uraí, Assai, Londrina e Bandeirantes, após a primeira Guerra Mundial. Nos Campos Gerais, os holandeses fundaram em 1911 o núcleo de Carambeí, no município de Castro, e também a colônia de Castrolanda. Os alemães menonitas vieram de Santa Catarina e instalaram-se na colônia Witmarsun, em Palmeira.

\section{A constituição das escolas étnicas na Província do Paraná}

Depois da emancipação da Comarca de São Paulo, a educação na Província do Paraná encontrava-se em estado precário. Até então, por ser uma extensão da economia paulista, a relação com a Comarca, devido à distância, era de descaso e negligência com as necessidades do interior. Apenas uma minoria da população frequentava os cursos de primeiras letras, o ensino secundário era praticamente inexistente e o pouco que havia em Curitiba atendia a demanda local e do interior da Província. A máquina administrativa recém constituída foi representada por homens que se dedicavam ao comércio, e um dos desafios dessa elite era atrair os governados para sua administração. A instrução pública foi utilizada para chamar a atenção da população, pois além de o Governo conquistar maior visibilidade por meio da educação, teria também mão-deobra melhor formada.

O ensino na Província foi organizado por meio do Regulamento de 1857, que estipulava a criação de escolas públicas e particulares. As primeiras ministravam o ensino gratuito a todos, com exceção das casas de Asilo, que atendiam os indigentes; e as segundas eram mantidas por particulares ou associações, sendo habilitadas e inspecionadas pelo Governo.

O Regulamento também garantia a obrigatoriedade do ensino como uma das alternativas para a frequência escolar, mas discriminava socialmente os escravos, que eram proibidos de matricular-se nas escolas. Essa exigência da legislação, de teor aristocrático, refletia os interesses e as necessidades da sociedade da época, uma sociedade baseada na escravidão, para quem a instrução representava apenas um meio para perpetuar a dominação.

Para que fosse cumprida a obrigatoriedade do ensino, estabelecida pelo Regulamento, ficou estipulado que o Estado financiaria os alunos que precisassem de ajuda material, pois de outra forma elas não frequentariam a escola. Os meninos pobres receberiam papel, penas, tintas, livros e compêndios necessários para o ensino. Nas escolas públicas e particulares só seriam admitidos livros autorizados pelo inspetor 
geral. A fiscalização do ensino primário na Província era exercida por uma comissão de três membros: um nomeado pelo governo da Província e dois, pela Câmara Municipal.

Em 1871 um novo regulamento é decretado, passando a tratar da instrução pública primária e do ensino particular. Estabelecia que a instrução seria gratuita, incluindo no programa a instrução religiosa, que visava às orações e ao catecismo, abrangendo o velho e o novo testamento. Nas escolas do sexo feminino, além das matérias de leitura, caligrafia, gramática, língua nacional e aritmética, seriam ensinados os diversos trabalhos de agulha.

Cinco anos mais tarde foi aprovado o Regulamento Orgânico da Instrução Pública, considerado como uma legislação completa e a mais bem elaborada do período provincial. O objetivo desse Regulamento foi de reestruturar as diretrizes educacionais do ensino público e determinar a obrigatoriedade da frequência às aulas.

A implantação da Escola Normal em Curitiba, no final do século XIX, procurou amenizar um dos mais sérios debates do setor educacional, que era a formação de professores.

A partir desse quadro educacional bem modesto e precário, nas diversas tentativas de organização da instrução pública na Província do Paraná, por meio da aprovação dos Regulamentos citados anteriormente, o ensino paranaense esbarrou em diversas dificuldades. A falta de escolas e de profissionais para seu provimento, os baixos índices de escolarização, os escassos investimentos governamentais no ensino refletiram-se em uma escola elitista, a qual cumpria um papel social de reproduzir a realidade, mantendo a discriminação social e a dominação.

Assim que se estabeleceram os imigrantes procuraram inserir-se na sociedade, como meio primordial para sua existência e manutenção nas novas terras. Por meio da sua inserção, poderiam manter contato com a população e assim comprar e vender seus produtos. Um dos meios para essa inserção se deu pelo aprendizado da língua portuguesa.

É preciso compreender que a escola pública adquiriu, para os imigrantes alemães, importância muito maior do que na própria Alemanha, pois aqui a escola pública lhes ia administrar o conhecimento do português, instrumento de comunicação do meio em que eram destinados a viver. (WILLEMS, 1980, p. 275).

Entretanto, logo perceberam que o ensino era deficiente, precário e sequer atendia à maioria das crianças brasileiras em idade escolar. Os imigrantes, como em sua terra de origem, consideravam que as autoridades deveriam prover a população com a instalação de escolas públicas nos núcleos coloniais. Com o quadro educacional paranaense desanimador, eles criaram as suas próprias escolas, responsabilizando-se pela instalação e manutenção, tanto do professor quanto da estrutura escolar. Cabe destacar ainda, que as escolas criadas pelos imigrantes atendiam também a população brasileira que residia próximo das colônias.

Ao final do governo imperial era possível quantificar as poucas escolas existentes que atendiam a população brasileira. O quadro geral contava com alguns liceus nas capitais, colégios privados instalados nas principais cidades e escolas normais em quantidade insatisfatórias para a formação do magistério. É perceptível o caráter elitista e discriminatório na educação brasileira, o ensino trazia resquícios da época de sua implantação, ou seja, era voltado para o atendimento da elite, sem nenhum compromisso com as classes populares, principalmente filhos de escravos e imigrantes.

Conforme registros do Relatório do Presidente da Província, Zacarias de Góes e Vasconcellos, (1854) estabeleceu-se, em 1847, nas terras paranaenses a colônia de 
imigrantes franceses fundada pelo médico Dr. João Mauricio Faivre. A Colônia Tereza, designada como forma de homenagear a Imperatriz Tereza Cristina localizava-se no interior da Província, às margens do rio Ivaí, a $230 \mathrm{~km}$ de Curitiba e era subvencionada pelo estado. Após a morte do seu fundador, assumiu a direção Gustavo Rumblsperger. Em 1861 a colônia contava com 299 habitantes e possuía duas escolas para ambos os sexos com duas professoras nomeadas pelo governo. Também havia na colônia uma escola particular que ministrava aulas de francês, desenhos e trabalhos com agulha.

Nesta colônia a escola funcionou nos primeiros anos após a sua fundação em caráter particular com professores designados pela comunidade e oferecia aulas de primeiras letras (leitura, escrita e canto). Somente em 1857 a escola passou a contar com a subvenção da província e atendia 30 alunos. Atendia também, 32 meninos nas aulas de primeiras letras, regida pelo Francês Felix Antonio Condamine e cerca de 25 meninas, atendidas por D. Vitalina da Rosa, sem utensílios ou móveis para atender as necessidades dos alunos. No ano de 1861 a escola atendia ainda 32 meninos, entretanto, há um crescimento quantitativo no atendimento feminino, a professora passou a atender 35 meninas.

Em 1852 instalou-se no segundo Distrito de Paranaguá, a Colônia Superagui, fundada por Carlos Perret Gentil, natural da Suíça. A colônia era formada por dez famílias suíças, cinco francesas e duas alemãs, num total de 64 pessoas. Já, em 1856 a colônia contava com 88 famílias e 403 pessoas e até aquele momento não contavam com escola. Os imigrantes reivindicavam a construção de uma escola e de uma igreja, bem como a vinda de um professor e de um padre. "É aqui ocasião de lembrar-vos uma das necessidades apontadas pelo diretor da colônia do Superaguy: reporto-me à criação de uma escola de instrução primaria ali". (PARANÁ, 1861, p. 5). Entretanto, a partir de 1861 a escola passou a atender somente os meninos, sob a inspeção do Dr. Francisco Ferreira Correa.

Neste contexto, marcado pelas dificuldades de colonização e instalação das colônias o governo paranaense justificou da seguinte forma a ausência de escolas:

A falta de pessoal habilitado para o magistério, apesar das vantagens que o tendes cercado, a dessiminação da pouca população, por um vasto territorio, a falta de meios de uns, e nenhuma importância que outros ligam à cultura da intelligencia, e que os faz distrahir os filhos das scholas [...]. (PARANÁ, 1859, p. 15).

A situação do ensino paranaense neste período caracterizou-se pela existência de escolas isoladas que apresentavam funcionamento precário, baixo número de alunos matriculados e falta de professores qualificados. Havia em toda a província do Paraná, no ano de 1882, apenas 133 escolas públicas; dessas somente 91 funcionavam com cerca de 20 alunos. (PARANÁ, 1882).

Em 1860 o governo paranaense anunciou a formação da Colônia do Assungui, formada por ingleses, franceses, italianos e alemães, dirigida por Joaquim Pinto de Queiroz Sarmento. No ano seguinte foi nomeado o professor Carlos Moericofer para "[...] instruir nas noções das letras [...]" (PARANÁ, 1861) os fillhos dos colonos.

A escolarização das crianças, filhas de imigrantes, se deu por meio das reivindicações das famílias pela construção e manutenção de escolas públicas, a fim de garantir a aprendizagem da língua nacional.

A falta de escola, no pensamento do imigrante, gerava o risco de que seus filhos ficassem desumanizados, ignorantes. [...]. Assim, a escola 
era representada como uma instituição que deveria ser preservada para a manutenção da cultura letrada. (MASCHIO, 2007, p. 170)

Entretanto, quando não era possível manter escolas públicas os próprios imigrantes se organizavam para oferecer educação para seus filhos. Em 1876, a colônia do Assungui possuía três escolas de instrução primária que atendiam 53 meninos e 41 meninas, sendo que duas eram mantidas pelo governo paranaense e uma mantida pelo Ministério da Agricultura.

Diante deste contexto de precariedade e descaso com a instrução pública, os ideais propagados pelos dirigentes defendiam a necessidade de instruir a população como meio de regenerá-la e assim torná-la apta para participar do progresso do país. Para tanto, a instrução cumpriu um papel fundamental, ou seja, permitiria que o Império brasileiro se colocasse ao lado das nações civilizadas. A instrução da população possibilitaria romper as trevas que caracterizavam o passado colonial; bem como possibilidade de estabelecer o primado da Razão, superando a 'barbárie dos Sertões' e a 'desordem' das Ruas; além da oportunidade de usufruir os benefícios do progresso (MATTOS, 1990)

Todo o sacrificio empregado neste importante ramo do serviço publico é generosamente indemnisado pela illustração indispensável aos povos livres. Dai-nos a educação da primeira infancia nós reformaremos a sociedade, disseram-o sucessivamente, cada um em sua linguagem, Bacon na Inglaterra, Leibnitz na Allemanha, Fenélon e João Jacques Reusseau em França [...]. (PARANÁ, 1856, p. 14)

A constituição de escolas primárias foi gradual e lenta na província paranaense e as poucas que foram criadas, muitas funcionavam em estado precário, com falta de materiais e utensílios, e muitas vezes não haviam professores disponíveis para atuar neste nível e nem local adequar para o prédio escolar. Muitas escolas funcionavam nas casas dos professores, em locais impróprios e inadequados para as crianças. Neste sentido, pode-se inferir que a educação no período imperial foi marcada por um caráter elitista e discriminador, pois o ensino ainda apresentava resquícios da época colonial, ou seja, não havia nenhum compromisso com a instrução da população. As tentativas para organização do ensino público, tomadas pelos governantes da província, esbarravam na estrutura centralizadora do Império. Como o governo não priorizou o ensino público passou a apoiar as iniciativas particulares para a manutenção da instrução na província. Em muitas colônias de imigrantes europeus, surgiram escolas particulares, criada por iniciativa da comunidade e subvencionadas pelo governo (WACHOWIVZ, 1984).

A análise empreendida nos relatórios de governo demonstrou a necessidade e o interesse para a difusão da instrução pública no Paraná. Entretanto, a disseminação e a organização do ensino não obteve êxito, pois esbarrou na falta de investimentos e recursos financeiros necessários para ampliação do atendimento escolar. Para os governantes paranaenses todos os esforços estavam sendo empreendidos em prol da educação paranaense, conforme discurso de Lamenha Lins afirmando que "Nesta província, é licíto dizel-o, muito se tem feito em prol da instrucção publica.(PARANÁ, 1876, p, 42), porém, se os esforços não foram alcançados ainda justificava-se devido as seguintes causas: a falta de professores habilitados pela Escola Normal; o desconhecimento das vantagens inerentes da educação por parte dos pais e a consequente ausência dos alunos e, dentre outras, a ineficaz fiscalização nas regiões distantes do centro urbano (PARANÁ, 1876). 
Contudo, os esforços proclamados e envidados em prol da educação não justificavam os resultados alcançados pelo governo. Segundo o relatório de 1876 havia um indivíduo matriculado na escola para cada quatro habitantes, sendo que havia 96 estabelecimentos de ensino primário na província, com 3.183 alunos matriculados e apenas 2.267 frequentando as aulas.

Os resultados apontados indicam as dificuldades enfrentadas pelos imigrantes para fixação no território paranaense. A maioria das colônias, instaladas no Paraná, estava localizada em regiões desfavoráveis para a plantação e que eram desprezadas geográfica e economicamente pelo governo. Diante das dificuldades impostas os imigrantes precisaram se adaptar com as condições encontradas seja desenvolvendo atividades na colônia, trabalhando na construção de estradas ou nos centros urbanos.

A partir de 1875 a província do Paraná recebeu um número significativo de imigrantes italianos que se instalaram na Colônia Alexandra, situada a $14 \mathrm{~km}$ de Paranaguá, por meio de um contrato firmado entre o Presidente, Venâncio José Lisboa e o empresário Sabino Tripodi. Apesar da colônia tem uma boa estrutura administrativa e econômica não possuía escola, igreja, enfermaria e nem estrada central para comunicarse com o porto de embarque (PARANÁ, 1876). Logo após sua instalação, Sabino Tripodi, declarou ao governo paranaense que não possuía meios para manter os imigrantes que havia trazido e estes acabaram sofrendo as consequiências da falta de planejamento e interesse dos agentes da imigração. Com a situação da colônia Alexandra lastimável, o governo decidiu remover os imigrantes italianos para a região de Morretes e, ainda, instalar novos imigrantes que continuavam a chegar.

Em muitas colônias, diante da precariedade e da falta de professores habilitados, os próprios colonos se organizaram e assumiram essa função. Em virtude da demora de atendimento pelo governo os próprios colonos providenciaram a construção da igreja e do cemitério. A escola foi viabilizada posteriormente (MASCHIO, 2007). Após os esforços dos imigrantes italianos para reivindicar a construção de uma escola na colônia, a primeira escola pública de primeiras letras foi criada em 1882, sendo nomeado o professor Antonio José de Souza Guimarães.

As escolas públicas de ensino primário não eram suficientes para atender ao número de crianças em idade escolar e os conteúdos ministrados estavam em desajuste com as necessidades sociais, pois se reduziam aos ensinamentos básicos de ler, escrever, contar e instruir moral e religiosamente. $\mathrm{O}$ currículo ministrado nas escolas públicas não atendia às necessidades e interesses da camada média da população, constituída por negociantes, fabricantes, lavradores, empregados públicos e artistas que frequentavam as escolas (OLIVEIRA, 1982).

A educação primária, destinada mais à preparação de uma elite do que à alfabetização do povo, desenvolveu-se no regime imperial marcada fortemente pelas "[...] tradições intelectuais do país, pelo regime de economia patriarcal e pelo ideal correspondente de homem e de cidadão" (AZEVEDO, 1996, p. 560). O modo de produção no Brasil-colônia era fundamentado na exploração e produção de gêneros tropicais ${ }^{4}$ para exportação, e o processo baseava-se no envio dos produtos para a metrópole, para distribuição e comercialização. O colono e o escravo em nenhum momento desenvolveram uma estrutura interna capaz de mobilizar e acumular capitais. Portanto, a colônia esteve à margem do surgimento do sistema capitalista, participando como coadjuvante na formação dessa nova economia. A colônia apenas fornecia os produtos e não compartilhava dos aspectos sociais e econômicos do sistema capitalista. A economia colonial pode ser definida como: 
[...] altamente especializada e complementar à economia metropolitana. Esta complementaridade se traduz num determinado padrão de comércio: exportam-se produtos coloniais e se importam produtos manufaturados $\mathrm{e}$, no caso de economias fundadas na escravidão negra, escravos. Por outro lado, a articulação economia metropolitana-economia colonial a isto não se resume, porque este padrão de comércio se efetiva através do monopólio de comércio exercido pela burguesia comercial metropolitana (MELLO, 1998, p. 39).

Por conseguinte, durante o Império, predominou a economia baseada na agricultura e no trabalho escravo, porém, essa situação alterou-se a partir da segunda metade do século XI. O processo de abolição, que se deu de forma progressiva, através de vários mecanismos e leis, como a proibição do tráfego negreiro, a Lei do Ventre Livre e, finalmente, a substituição do trabalho servil pelo trabalho livre, foi o golpe decisivo para a proclamação da República.

A partir da proclamação da República a legislação educacional paranaense passou a enfatizar a necessidade do ensino da língua nacional nas escolas estrangeiras. Para os governantes, a língua nacional era um critério importante como instrumento formador da nação brasileira. Assim, para a formação da nação, era necessário que as escolas de imigrantes ensinassem a língua pátria e enfatizassem o ensino do Hino Nacional e da Bandeira Nacional, como também a história e a geografia do país.

Com a difusão lenta da escola pública, estadual e municipal, iniciou-se a competição com a escola paroquial ou comunal dos teutos-brasileiros. À primeira vista poderia parecer que a última, por corresponder a uma experiência quase secular dos colonos, dificilmente pudesse ser desalojada pela escola pública que era recebida com reserva ou desconfiança pelos teutos conservadores (WILLEMS, 1980, p. 289).

Isso demonstra que a preocupação da escola pública - instrumento de transmissão dos ideais liberais - com a nacionalização dos imigrantes, desencadeou neles sentimentos de desconfiança, rejeição e, mesmo, de resistência, em relação a essa escola. Em outra perspectiva, os estudos de Kreutz (2000), afirmam que a ênfase na formação da nacionalidade tem relação com a tendência de afirmação da unidade, estabelecendo um espaço hierarquizado em que se definia o que seria entendido como verdadeiramente nacional e o que seria excluído dessa compreensão.

Buscava-se um pretenso coletivo, operava-se uma universalização no conceito de povo e de nação em detrimento das especificidades e diferenciações culturais. $\mathrm{O}$ nacionalismo desencadeava um movimento de afirmação de uma unidade simbólica, necessária pela modernização econômica. Apoiava-se na expansão de um sistema escolar igualitário, com a função de difundir uma cultura uniforme. Inventava culturas amplamente desprovidas de toda base étnica, com a finalidade de unificar o imaginário das nações. (KREUTZ, 2000, p. 351)

E nesse processo de configuração de uma identidade nacional, a escola foi chamada a desenvolver nos alunos, principalmente naqueles de origem européia, a idéia de que os conhecimentos tratados numa perspectiva generalizante são superiores aos saberes particulares. A escola "deveria ser ativada em perspectiva monocultural, tratando as diferenciações culturais como algo a ser superado" (KREUTZ, 2000, p. $352)$. 
A partir da década de 1920, intensificou-se a fiscalização nas escolas estrangeiras por parte do governo. No Relatório de 1921, o diretor da Instrução Pública relata o fechamento das escolas estrangeiras, cujo funcionamento condicionava á aprovação nos exames de professores efetivos.

\begin{abstract}
Nas colônias extrangeiras e villas, onde a inspecção official determinou o fechamento de escolas, por ser a nossa lingua de todo desconhecida, quer dos professores, quer dos alumnos, apezar destes terem nascido aqui, começa agora a reflectir-se a nova acção, apparecendo de tempos em tempos um requerimento, no qual se pede autorisação para a reabertura de escolas. Nos exames de Dezembro para professores effectivos, houve alguns candidatos, de nacionalidade polaca, que foram approvados com excellentes notas e que por isso tiveram ordem de poder abrir suas escolas, sob a condição de todo o ensino ser ministrado em portuguez e figurar no programma a Historia e a Geographia pátrias. (PARANÁ. RELATÓRIO, 1921, p. 68).
\end{abstract}

Encontram-se, no Código de Ensino de 1917, no Título V, as disposições que tratam das escolas particulares. Quanto ao ensino da língua nacional, é estabelecido como obrigatório em todas as escolas primárias ou secundárias. No que se refere ao programa, os professores deveriam ensinar a Língua Nacional, Geografia e Corografia do Brasil e História do Brasil, dando ênfase às idéias de nação. A fiscalização das escolas estrangeiras ficaria a cargo do Secretario do Interior, Justiça e Instrução Pública, dos delegados e inspetores de ensino.

Pode-se afirmar que essa política de nacionalização das escolas estrangeiras surtiu o efeito que o governo planejou. Muitas escolas estrangeiras foram fechadas, principalmente as de origem alemã, agravando-se essa situação com o início da Primeira Guerra Mundial. Entretanto, as escolas que continuaram funcionando conseguiram manter viva a cultura do seu país de origem.

\title{
Referências
}

ABREU, Y. V. de. Visões sobre a economia colonial: a contribuição do negro. Espanha: Eumed.Net, Universidade de Málaga, 2009.

AZEVEDO, F. A cultura brasileira: introdução ao estudo da cultura no Brasil. Brasília: UNB, 1996.

BAlHANA, A. P. et al. História do Paraná. Paraná: Grafipar, 1969.

Quantitativo dos imigrantes entrados no Paraná. In: Dicionário histórico - biográfico do Estado do Paraná. Curitiba: Chaim, 1991.

COSTA, E. V. da. Da Monarquia à República. Momentos decisivos. São Paulo: Unesp, (8a edição revista e ampliada), 2007.

DIÉGUES JUNIOR. M. Imigração, urbanização e industrialização. Rio de Janeiro: INEP, 1964.

GOHN, M. da G. História dos movimentos e lutas sociais. A construção da cidadania dos brasileiros. São Paulo: Loyola, 1995. 
IANNI, O. As metamorfoses do escravo. 2.ed. São Paulo: Hucitec, 1988.

KOSIK, K. Dialética do concreto. São Paulo: Paz e Terra, 1995.

KOWARICK, L. Trabalho e vadiagem: a origem do trabalho livre no Brasil. 2. ed. Rio de Janeiro: Paz \& Terra, 1994.

KREUTZ, L. A educação de imigrantes no Brasil. In: LOPES, E. M. T.; FARIA FILHO, L. M.; VEIGA, C. G. 500 anos de educação no Brasil. Belo Horizonte: Autêntica, 2000.

O Professor Paroquial: Magistério e Imigração Alemã. Porto Alegre: Ed. da Universidade/UFRGS; Florianópolis: Ed. da UFSC; Caxias do Sul: EDUCS, 1991.

LUPORINI, T. J. Escolas de imigrantes na região dos Campos Gerais e centro sul do Paraná. In: LOMBARDI, J. C.\& MACHADO, M. C. G.\& SCHELBAUER, A. (Org.). Educação em Debate. Perspectivas, Abordagens e Historiografia. Campinas: Autores Associados; 2006, p. 301 -322.

MASCHIO, E. C. F. Educação, mutualismo e nacionalização: aspectos de uma escola étnica italiana no Paraná (1905-1918). Roteiro, Joaçaba, v. 32, n. 2, p. 167-182, jul./dez. 2007.

MATTOS, I. R. de. O Tempo Saquarema: a formação do Estado imperial. 2 ed. São Paulo: Hucitec, 1990.

MELLO, J. M. C. de. O capitalismo tardio: contribuição à revisão crítica da formação e do desenvolvimento da economia brasileira. Campinas, SP: UNICAMP, 1998.

NASCIMENTO, M. I. M. A Primeira Escola de professores dos Campos Gerais - PR. Ponta Grossa: Editora UEPG, 2008.

OLIVEIRA, M. C. M. de. O ensino primário na província do Paraná, 1853-1889. Dissertação. Mestrado em História. Universidade Federal do Paraná, 1982.

PADIS, P. C. Formação de uma economia periférica: o caso do Paraná. 2. ed. Curitiba: IPARDES, 2006.

PARANÁ. Relatório do Presidente da Província do Paraná o conselheiro Zacarias de Góes e Vasconcellos na Abertura da Assembléa Legislativa Provincial em 15 de julho de 1854. Curitiba: Typ. Paranaense de Candido Martins Lopes, 1854.

Relatório do Presidente da Província do Paraná Francisco Liberato de Mattos na Abertura da Assembléa Legislativa Provincial em 7 de janeiro de 1859. Curitiba: Typ. Paranaense de Candido Martins Lopes, 1859.

Relatório do Presidente de Província do Paraná, Presidente José Francisco Cardoso na Assembléia provincial em 18 de Março de 1861. Typ. Paranaense, Curitiba, 1861.

Relatório do Presidente da Província do Paraná André Augusto de Pádua Fleury na Abertura da $2^{a}$ Sessão da $7^{\mathrm{a}}$ Legislatura em 21 de março de 1865. Curitiba: Typ. Paranaense de Candido Martins Lopes, 1859.

Relatório apresentado a Assembléia Legislativa Provincial do Paraná em 15 de fevereiro de 1875 pelo presidente Araujo Abranches. Curityba : Typ. Da Viúva Lopes, 1875. 
Relatório apresentado á Assembleia Legislativa do Paraná no dia 15 de fevereiro de 1876 pelo presidente da província, doutor Adolpho Lamenha Lins. Província do Paraná, Typ. da Viúva Lopes, 1876.

Relatório do Presidente da Província apresentado à Assembléia Legislativa do Paraná, em 16 de fevereiro de 1881, pelo Dr. João José Pedrosa. Curitiba: Ed. Typ. Perseverança - de J. Pinheiro, 1881.

Relatório apresentado ao Secretário Geral do Estado pelo Professor Cesar Prieto Martinez, Inspetor Geral do Ensino. Curitiba: Tip. Da Penitenciária do Estado, 1921.

TRINDADE, E. M. de C. \& ANDREAZZA, M. L. Cultura e educação no Paraná. Curitiba: SEED, 2001.

SAVIANI, D. História das ideias pedagógicas no Brasil. Campinas: Autores Associados, 2010.

VAINFAS, R. (org.). Dicionário do Brasil Imperial. Rio de Janeiro: Objetiva, 2002.

WACHOWICZ, L. A. A relação professor-estado no Paraná tradicional. Curitiba: Cortez, 1984.

WILLEMS, E. A aculturação dos alemães no Brasil. São Paulo: Ed. Nacional, 1980.

Notas

\footnotetext{
${ }^{1}$ Em 1810, Dom João assinou o Tratado de Comércio e Navegação com a Inglaterra, comprometendo-se com o fim do comércio de escravos. Entretanto, com a oposição dos grandes proprietários de terras o tráfico de escravos continuou persistindo durantes anos. Em 1827, um decreto imperial garantiu o fim do comércio negreiro no prazo de quatro anos. Em 1831 entrou em vigor uma lei que determinou o fim do tráfico, porém, nunca foi posta em prática.

${ }^{2}$ Termo utilizado nas mensagens dos presidentes da província para designar o trabalhador livre que retirava da natureza os meios de sobrevivência, considerado como um indivíduo preguiçoso (Saint - Hilaire, 1979).

3 As teorias do branqueamento surgiram baseadas na convicção de que o elemento considerado racionalmente superior" - ou seja, o branco - predominaria nos processos de mistura de raças. O processo de imigração europeia foi um meio de oferecer o processo de branqueamento biológico e cultural da futura população brasileira (VAINFAS, 2002, p. 618).

${ }^{4} \mathrm{O}$ setor exportador produzia, em larga escala, produtos coloniais, tais como: açúcar, tabaco, metais preciosos, madeiras etc.
}

Recebido em agosto-2013

Aprovado em setembro-2013 